\title{
非円形歯車を用いた可変剛性関節
}

\author{
松 田 壮 史*1 村 田智*2
}

\section{Variable Stiffness Hinge Using Non-Circular Gears}

Takeshi Matsuda*1 and Satoshi Murata*2

\begin{abstract}
This paper presents design of a new antagonistic variable stiffness hinge using noncircular gears. First, we show a method to convert a torsion spring to an arbitrary nonlinear torsion spring by nonuniform circular motion of noncircular gears. This nonlinear torsion spring is called $\rho^{2}$-Spring. Next, a pair of $\rho^{2}$-Springs are connected antagonistically to comprise a variable stiffness joint. Moreover, the design method of $\rho^{2}$-Spring and $\beta^{2}$-Hinge which have arbitrary characteristic is developed. We explain the characteristics of this joint theoretically and evaluate its capability of wide range stiffness. We also present experimental results of the prototype.
\end{abstract}

Key Words: Variable Stiffness, Antagonistic Mechanism, Impedance Control, Noncircular Gear, Nonlinear Spring

\section{1. はじ’めに}

近年のロボット技術の発展は目覚しく, 閉ざされた空間で活 動する産業用ロボット以外にも, 家庭, 学校や病院, 商業施設 など，不特定の一般の人々が存在する，開かれた空間での応用 が模索されるようになってきている。こういった非製造業分野 では, 人間との衝突が生じやすい環境で活動するため, より高 い安全性が求められる.

現在主流となっているロボットは, シリアルリンクマニピュ レータを基本とし，ロボット関節にインピーダンス制御を行い, 見かけ上のやわらかさを付与することで, 安全性を確保してい る.しかしながらこの方式では, フィードバック系に遅れが存 在するため, 想定を超える衝撃には対応できず，また制御器そ のものの故障に起因する, 異常動作等の危険性も排除できない. これらは, 制御系のみでは対応が難しい問題である.

本質的に安全なロボットのための受動的な機構として, 可変 剛性関節に注目が集まっている [1].これはバネなどの弾性要素 によって衝撃を吸収するだけではなく，その剛性係数や関節角 を任意に設定できる関節機構のことである.

またロボットに機械的な弾性体を埋め込むことは，高速応答 性やエネルギー効率の面からも有用である. ヒトの歩行は, 足 の振り自体はそれほど早い周期を持つ運動ではないが，ロボッ トにおいて足関節にアクチュエータを直結させこの運動をさせ

原稿受付 2006 年 4 月 20 日

$* 1$ 株式会社インクス
*2 東京工業大学
${ }^{* 1}$ INCS Inc.
${ }^{* 2}$ Tokyo Institute of Technology
ることを考えた場合，バランスを取るために，足の振りよりは るかに高い周波数応答を持ったアクチュエータが必要になる。一 般にロボットに使わ机る電磁モータでは, トルクを確保するた め高減速率のギアを使用しており，必要な周波数応答を実現す ることは容易でなく，ロボットのコストを上げる原因となってい る、またエネルギーを回生することが難しいため，エネルギー 効率も悪い。一方, 可変剛性関節を使用することにより, 内蔵 される弾性体と足との間で高速にエネルギーを循環させること ができるので，機敏な動きと高エネルギー効率を両立すること が可能である.

可変剛性関節は, 構造上の特徵からいくつかの種類に分けら れるが,ここではヒトが拮抗筋構造により剛性制御を可能にし ている [2]ことを模倣した「拮抗駆動型」可変剛性関節 [3] に着 目する。これは非線形弾性特性を持つ機構系を二つ用いて, そ れらを直接拮抗させ接続するものである. 非線形弾性特性を持 つ要素を用意すればよいため, 原理的には容易に可変剛性関節 を構成できる。しかしながら設定可能な剛性範囲を幅広く取る ためには, 非線形性が強い弾性要素が必要であり, 単一の機械 要素（特殊なバネなど）によってこれを実現することは難しい. これまでの研究では, 試作レベルを超えることができないのが 現状である.

そこで本研究では, 非円形歯車の利用によりこの問題の解決 を図る。非円形歯車とはピッチ曲線を任意の曲線とすることで, 簡潔な機構で任意の不等速回転を得ることのできる要素である. これを任意の弾性要素の変位の非線形伝達に利用することで, 小型で摩擦が少なくかつ幅広い特性変化範囲を持つ非線形弾性 
要素を作り出すことができる†。

本論文の構成は以下の通りである。第 2 章では，まず代表的 な可变剛性関節の研究についてまとめた上で，それらの問題点 を指摘する．第 3 章では非円形歯車の基礎について述べる．第 4 章では非以形歯車を用いた非線形弾性要素 $\left(\rho^{2}\right.$-Spring $)$ を提 案し，その特性を明らかにする．第 5 章では $\rho^{2}$-Spring を二つ 使い，それを拮抗筋の上うに接続することで得られる可変剛性 関節 $\beta^{2}$-Hinge を提案し，その特性を明らかにする，さらに第 6 章では，任意の変位-負荷特性を実現する $\rho^{2}$-Spring と任意の 可変剛性特性を持つ $\beta^{2}$-Hinge の, それぞれの設計手法を構築 する．最後に第 7 章において試作機による実験の結果を示し， 提案する設計理論の正当性を検証する.

\section{2. 可変剛性関節の従来研究}

本章では，これまでに研究されてきた代表的な可变剛性関節 の問題点について述べる.

可変剛性関節には，すでに述べた拮抗駆動型と呼ばれるもの 以外にも，「直接駆動型」と分類されるものがある。これは単一 の機構によって可変剛性特性を実現するものである.

\section{1 直接駆動型}

直接駆動型の代表として，板バネを用いる方式を取り上げる。

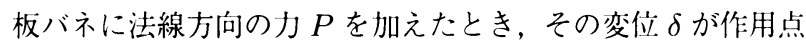
Cの位置によって変化することを利用した機構である（Fig. 1)． シンプルな機構となるため，ロボットアームなどに応用されて いる [6]. しかし $a$ が $b$ に比べ小さくるにつれ急激に剛性が上 昇してしまうことを原理的に回避できないなど，設計自由度の 少なさが問題である。

\section{2 拮抗駆動型}

拮抗駆動型は，使用する非線形弾性要素の種類によって分類 される。

2.2.1 非線形コイルバネ (Nonlinear Coil Spring)

压縮されたときに，コイルバネが次第に密着するようにバネ のピッチを不等にしたものである（Fig. 2)。これにより，負荷

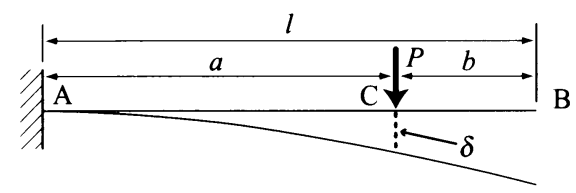

Fig. 1 Cantilever beam

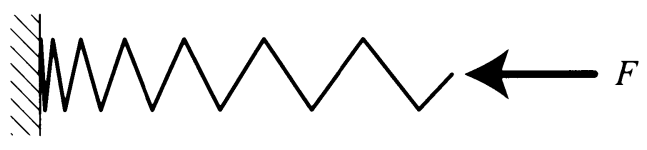

Fig. 2 Nonlinear coil spring

\footnotetext{
†同様のアイデアに基づくものとして，非円形プーリを使った Hurst ら の AMASC と呼ばれるが可変剛性機構がある [4]. これは, 受動的なや わらかさを尊入した脚ロボットの関節を想定して開発されており，拮抗 駆動型可変剛性関節に必要な非線形弾性要素を実現するために，不等速 回転伝達要素 (非円形プーリ) を利用する。しかしこの機構はワイヤを 多数使う複雑なものであり，また，非円形プーリには対数らせんを用い ているのみであり，任意の可変剛性特性を実現するピッチ形状の設計手 法の確立には至っていない。
}

に応じて連続的に有効巻数が变化し，非線形な変位一負荷特性を 実現している，しかし製作上の困難から，任意の変位一負荷特性 を得ることが難しいため，応用範囲が限られる。

\section{2 .2 案内棒とねじりバネを用いる方式}

テーパ状の案内棒にねじりバネ（torsion spring）を取り付け たもので，案内棒が回転すると次第にねじりバネが案内棒に巻 き付き有効巻数を減じることで非線形特性を実現する要素が提 案さ圠ている [8]. しかし巻き付いたねじりバネと案内棒の間に 存在する摩擦や，案内棒のテーパ形状に自由度があまりないこ とから，限られた用途にしか使えない。

2.2 .3 動滑車と線形バネを用いる方式

動滑車に線形バネを取り付け，動滑車を通じてワイヤの張力 を線形バネに負荷させることで, 非線形弾性要素を構成するも のである (Fig. 3) [9]. 動滑車と線形バネを対向させて設置す るためサイズが大きくなる傾向があり，さらにワイヤの伸びに 特性が敏感なため, 実際の応用には適さない。

\section{3. 非円形歯車の基礎}

本章では，非円形㐘車の基本的な理論を導入する．非円形歯 車のピッチ曲線設計手法や，任意のピッチ曲線への㐘形創成も すでに確立されている [10] [12]. 本章では, 以下の章で理論展 開に必要な事項についてのみ説明する。

任意形状の歯車が一つあり，2 軸の中心間距離が一定 $(C=$ const. $)$ としたときに，その柬車に対して適切にかみ合い 回転するピッチ曲線を持つ㐘車を常に求めることができる，た だし通常の円形㐘車と違い，一般に閉曲線にはならない。

\section{1 ピッチ曲線の導出}

任意の非円形㐘車対の模式四を Fig. 4 に示す。これは中心間 距離 $C$ が一定で, 駆動㐘車 (driving gear) の半径を $R_{1}\left(\theta_{1}\right)$, 同

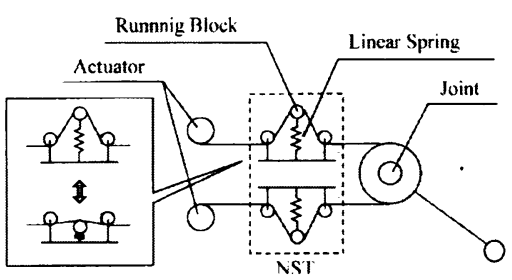

Fig. 3 Diagram of NST [5]

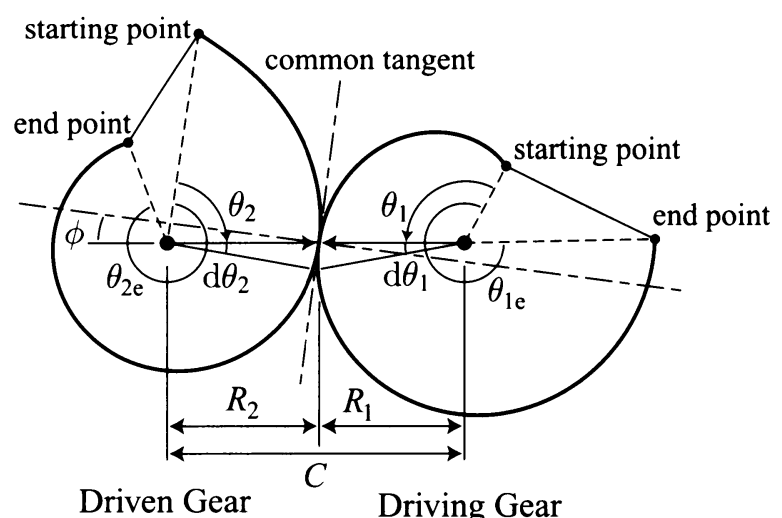

Fig. 4 Noncircular gears 
様に被動料車 (driven gear) の半径を $R_{2}\left(\theta_{2}\right)$ とし, 始点（starting point）から終点（end point）までのかみ合いを示したも のである、駆動歯車・被動歯車の回転角 $\theta_{1}, \theta_{2}$ は

$$
\left\{\begin{array}{l}
0 \leq \theta_{1} \leq \theta_{1 \mathrm{e}} \\
0 \leq \theta_{2} \leq \theta_{2 \mathrm{e}}
\end{array}\right.
$$

である．Fig. 4 において歯車は瓦いに滑らないこと，中心間距 離 $C$ が一定であることにより，

$$
\begin{gathered}
R_{1}\left(\theta_{1}\right) \mathrm{d} \theta_{1}=R_{2} \mathrm{~d} \theta_{2} \\
R_{1}\left(\theta_{1}\right)+R_{2}\left(\theta_{2}\right)=C
\end{gathered}
$$

が必要である，以上よりピッチ曲線は，

$$
\begin{gathered}
R_{1}\left(\theta_{1}\right)=\frac{C G\left(\theta_{1}\right)}{1+G\left(\theta_{1}\right)} \\
R_{2}\left(\theta_{1}\right)=C-R_{1}\left(\theta_{1}\right)=\frac{C}{1+G\left(\theta_{1}\right)}
\end{gathered}
$$

と一意に決定される。ただし実際に $R_{2}$ を求めるときには， $R_{2}$ を $\theta_{2}$ の関数に変数変換する必要がある，その変換式について は，次節で説明する．ここで $G\left(\theta_{1}\right)$ は角速度関係を規定する関 数で

$$
G\left(\theta_{1}\right)=\frac{\mathrm{d} \theta_{2}}{\mathrm{~d} \theta_{1}}
$$

と定義される.

非円形菌車対は終点でかみ合うので,

$$
\theta_{2 \mathrm{e}}=\int_{0}^{\theta_{1 \mathrm{e}}} G\left(\theta_{1}\right) \mathrm{d} \theta_{1}
$$

が必要である.

\section{2 傾斜角とかみ合い圧力角}

非円形㐘車に扔いては接触点に扔ける角度が一般に一定でな い.この傾斜角（ピッチ曲線圧力角）がある一定値を超えると， 㐘車のかみ合い拘束を保つことはできない。

傾斜角 $\phi$ は

$$
\phi=\tan ^{-1}\left(\frac{1}{R_{1}\left(\theta_{1}\right)} \frac{\mathrm{d} R_{1}}{\mathrm{~d} \theta_{1}\left(\theta_{1}\right)}\right)
$$

で与えら机る. 香取 [11]は，ピッチ曲線圧力角 $\phi$ の絶対值に基 準圧力角 の和を $50[\mathrm{deg}]$ 以下にすることを提案している.

\section{4. 非円形歯車による非線形弾性要素 $\rho^{2}$-Spring}

本章では，非円形歯車を用いることで，任意の変位一負荷特性 を持つ非線形弾性要素 $\rho^{2}$-Spring を提案し，その構成とその特 性を明らかにする。

$\rho^{2}$-SpringはFig. 5 に示すように，駆動軸（driving axis）に $n$ 個の非線形歯車対が直列に接続し，被動軸（driven axis）に変 位一負荷特性が $\tau_{\mathrm{u}}$ で表される弾性要素 (以下, 弾性源（elasticity source）と呼ぶ）が接続されているものである. 弾性源が持つ

†㐘形が基準円と交わる点における㐘形の接線と，その点を通る中心連結 線との角度。一般に20[deg] 程度.

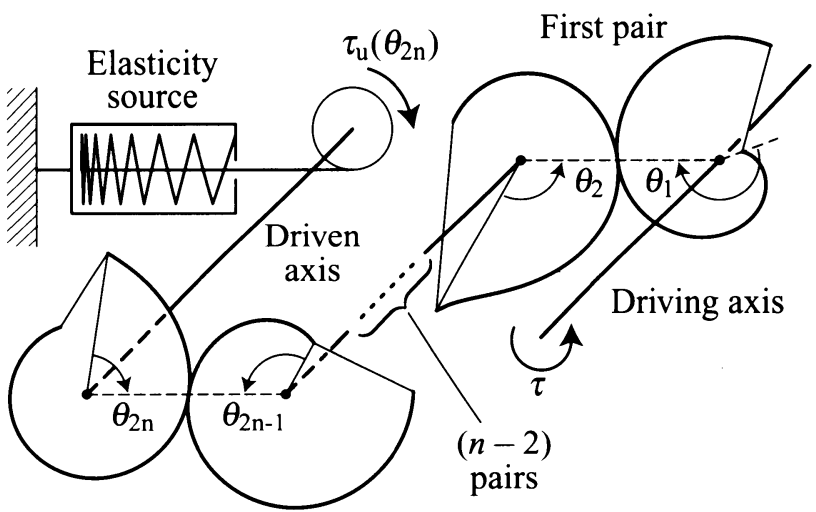

Final pair

Fig. $5 \rho^{2}$-Spring. $n$ pairs of noncircular gears with a nonlinear torsion spring attached

変位一負荷特性は, 線形・非線形のどちらでも構わない。

この機構は非円形歯車の特徵である, 小型で簡単な機構なが ら高効率で確実な動力伝達ができるという特長をそのまま持っ ており，また弾性源を選ばない. 非円形㐘車の設計次第で, 任 意の変位一負荷特性を持つ非線形弾性要素を実現することが可能 であり, 従来研究の問題点を解決しうるものである.

\section{1 一般形}

あるトルク $\tau$ を駆動軸に負荷したとき，初段対（first pair） の駆動㐘車が $\theta_{1}$ だけ回転し, 最終段対（final pair）の被動歯 車が $\theta_{2 \mathrm{n}}$ 回転することで, 最終段対の被動歯車に $\tau_{\mathrm{u}}\left(\theta_{2 \mathrm{n}}\right)$ なる トルクが付与される.

このとき，仮想仕事の原理より，

$$
\tau \mathrm{d} \theta_{1}=\tau_{\mathrm{u}}\left(\theta_{2 n}\right) \mathrm{d} \theta_{2 n}
$$

が成り立つ。

さてここで, 回転角 $\theta_{\mathrm{p}}$ と $\theta_{\mathrm{q}}$ 間の角速度比 $G_{\mathrm{p}, \mathrm{q}}\left(\theta_{\mathrm{p}}\right)$ を, 次 のように定義する.

$$
G_{\mathrm{p}, \mathrm{q}}\left(\theta_{\mathrm{p}}\right)=\frac{\mathrm{d} \theta_{\mathrm{q}}}{\mathrm{d} \theta_{\mathrm{p}}}
$$

同様に, 回転角 $\theta_{\mathrm{p}}$ から $\theta_{\mathrm{q}}$ への角度变換関数 $T_{\mathrm{p}, \mathrm{q}}\left(\theta_{\mathrm{p}}\right)$ を, 次の ように定義する.

$$
\theta_{\mathrm{q}}=T_{\mathrm{p}, \mathrm{q}}\left(\theta_{\mathrm{p}}\right)=\int_{0}^{\theta_{\mathrm{p}}} G_{\mathrm{p}, \mathrm{q}}\left(\theta_{\mathrm{p}}\right) \mathrm{d} \theta_{\mathrm{p}}
$$

入力したトルク $\tau$ と回転角 $\theta_{1}$ の関係は, 新しく定義した関 数 $G_{\mathrm{p}, \mathrm{q}}\left(\theta_{\mathrm{p}}\right), T_{\mathrm{p}, \mathrm{q}}\left(\theta_{\mathrm{p}}\right)$ を使用することで, 式 (9) より

$$
\begin{aligned}
\tau & =\tau_{\mathrm{u}}\left(\theta_{2 n}\right) \frac{\mathrm{d} \theta_{2 n}}{\mathrm{~d} \theta_{1}}=\tau_{\mathrm{u}}\left(\theta_{2 n}\right) \cdot G_{1,2 n}\left(\theta_{1}\right) \\
& =G_{1,2 n}\left(\theta_{1}\right) \cdot \tau_{\mathrm{u}}\left(T_{1,2 n}\left(\theta_{1}\right)\right)
\end{aligned}
$$

となる。この式は, $\rho^{2}$-Spring の駆動軸に $\theta_{1}$ なる変位があると きの出力トルクと見ることができるので, 変位一負荷関数 $\tau_{\mathrm{C}}(\theta)$ は

$$
\tau_{\mathrm{C}}(\theta)=G_{1,2 n}(\theta) \cdot \tau_{\mathrm{u}}\left(T_{1,2 n}(\theta)\right)
$$

となる（駆動軸の変位 $\theta_{1}$ を簡単のために $\theta$ と表記する）. 


\section{2 角速度比と角度変換関数の一般形}

前節では, 駆動軸から被動軸までの角速度比 $G_{1,2 n}$ と角度変 換関数 $T_{1,2 n}$ を用いた。駆動軸から被動軸までは, $n$ 個の非線形 歯車対によって直列に接続されているから， $G_{1,2 n}$ と $T_{1,2 n}$ は, それぞれの非線形歯車対が持つ角速度比 $G_{m, m+1}$ によって表現 できる。ただし $m$ は奇数である。

$\theta_{2 \mathrm{n}}$ は, $T_{\mathrm{p}, \mathrm{q}}\left(\theta_{\mathrm{p}}\right)$ の定義（式 $\left.(11)\right)$ と Fig. 5 において $\theta_{2 l+1}$ と $\theta_{2 l}$ ( $l$ は自然数 $)$ が同一となることに注意すると, 以下のよ うな入れ子状の合成関数によって表現できる.

$$
\theta_{2 n}=T_{2 n-1,2 n}\left(T_{2 n-3,2 n-2}\left(\ldots T_{3,4}\left(T_{1,2}\left(\theta_{1}\right)\right) \ldots\right)\right)
$$

したがって $T_{1,2 n}\left(\theta_{1}\right)$ は，以下のように求められる.

$$
T_{1,2 n}\left(\theta_{1}\right)=T_{2 n-1,2 n}\left(T_{2 n-3,2 n-2}\left(\ldots T_{3,4}\left(T_{1,2}\left(\theta_{1}\right)\right) \ldots\right)\right)
$$

合成関数の微分公式と式 $(14), \frac{\mathrm{d} \theta_{2 l+1}}{\mathrm{~d} \theta_{2 l}}=1\left(\because \theta_{2 l+1}\right.$ と $\theta_{2 l}$ $\left(l\right.$ は自然数) は同一) であることより, $G_{1,2 n}\left(\theta_{1}\right)$ は直ちに求 められて,

$$
\begin{aligned}
G_{1,2 n}(\theta) & =\frac{\mathrm{d} \theta_{2 n}}{\mathrm{~d} \theta_{1}} \\
& =\frac{\mathrm{d} \theta_{2 n}}{\mathrm{~d} \theta_{2 n-1}} \cdot \frac{\mathrm{d} \theta_{2 n-2}}{\mathrm{~d} \theta_{2 n-3}} \cdot \ldots \cdot \frac{\mathrm{d} \theta_{4}}{\mathrm{~d} \theta_{3}} \cdot \frac{\mathrm{d} \theta_{2}}{\mathrm{~d} \theta_{1}}
\end{aligned}
$$

となる。例えば $n=2$ では

$$
\left\{\begin{array}{l}
G_{1,4}\left(\theta_{1}\right)=G_{3,4}\left(T_{2,1}\left(\theta_{1}\right)\right) \cdot G_{1,2}\left(\theta_{1}\right) \\
T_{1,4}\left(\theta_{1}\right)=T_{3,4}\left(T_{2,1}\left(\theta_{1}\right)\right)
\end{array}\right.
$$

となる。

\section{5. 拮抗駆動型可変剛性関節 $\boldsymbol{\beta}^{2}$-Hinge}

本章では同一の $\rho^{2}$-Spring を一対組み合わせることで，拮抗 駆動型可変剛性関節（ $\beta^{2}$-Hinge）を構築する。これは $\rho^{2}$-Spring の小型・簡潔・高効率という特長を生かした可変剛性関節になる.

本論文で提案する $\beta^{2}$-Hinge は, $\rho^{2}$-Spring の駆動軸同士を 拮抗するように直接接続させるものであり,これを直接接続型 $\beta^{2}$-Hinge と呼ぶことにする.

直接接続型 $\beta^{2}$-Hinge の模式図を Fig. 6 に示す（本章の図で は弾性源を省略する)。二つの $\rho^{2}$-Spring $(\mathrm{A}, \mathrm{B})$ を，それぞれ の駆動軸が拮抗して接続するように， $\rho^{2}$-Spring B $\rho^{2}$-Spring A に対して反転させて接続している．接続された駆動軸を出力 軸（output axis）とし，その回転角を $\theta_{\mathrm{D}}$ とする。被動軸の位 置を設定するために，クランク状の設定軸（setting axis）を設 け，その回転角を設定角 $\theta_{\mathrm{sA}}, \theta_{\mathrm{sB}}$ と呼ぶ。これは被動軸の位置 は決定するが，被動軸とは空転するようにしているため，被動 軸の回転角 $\theta_{2 \mathrm{~A}}, \theta_{2 \mathrm{~B}}$ を直接決定するものではない。このとき， 明らかに以下の関係式が成り立つ。

$$
\left\{\begin{array}{l}
\theta_{1 \mathrm{~A}}=\theta_{\mathrm{sA}}-\theta_{\mathrm{D}} \\
\theta_{1 \mathrm{~B}}=\theta_{\mathrm{sB}}+\theta_{\mathrm{D}}
\end{array}\right.
$$

出力軸に負荷トルク $\tau_{\mathrm{add}}$ が加わり，出力軸が $\theta_{\mathrm{D}}$ となるとき

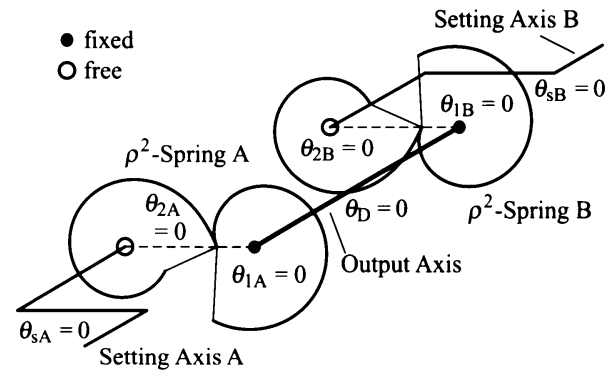

(a) Initial position

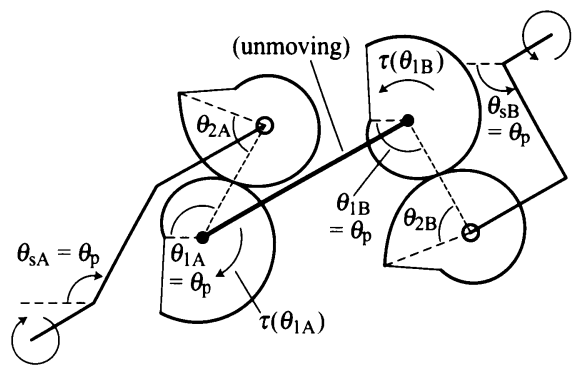

(b) Set $\theta_{\mathrm{sA}, \mathrm{sB}}$ to $\theta_{\mathrm{p}}$

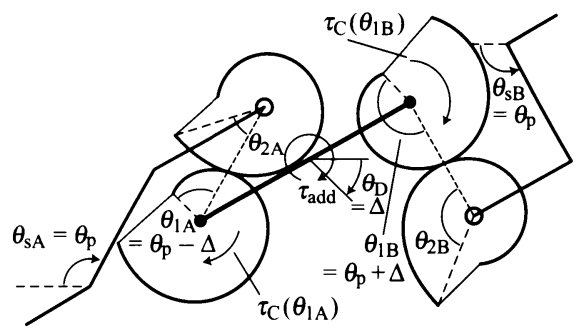

(c) Add external torque

Fig. 6 Antagonistic mechanism

を考える．出力軸における各トルクの関係は次のようになる.

$$
\begin{aligned}
& \tau_{\mathrm{C}}\left(\theta_{1 \mathrm{~A}}\right)+\tau_{\text {add }}-\tau_{\mathrm{C}}\left(\theta_{1 \mathrm{~B}}\right)=0 \\
& \therefore \tau_{\text {add }}=-\tau_{\mathrm{C}}\left(\theta_{1 \mathrm{~A}}\right)+\tau_{\mathrm{C}}\left(\theta_{1 \mathrm{~B}}\right)
\end{aligned}
$$

$\theta_{\mathrm{sA}}, \theta_{\mathrm{sB}}$ をある $\theta_{\mathrm{p}}, \theta_{\mathrm{q}}$ を使って

$$
\left\{\begin{array}{l}
\theta_{\mathrm{sA}}=\theta_{\mathrm{p}}+\theta_{\mathrm{q}} \\
\theta_{\mathrm{sB}}=\theta_{\mathrm{p}}-\theta_{\mathrm{q}}
\end{array}\right.
$$

と改めても一般性は失われない。ここで $\theta_{\mathrm{p}}$ を差動角， $\theta_{\mathrm{q}}$ を同 相角と呼ぶ。任意の值 $\Delta$ を用いて

$$
\theta_{\mathrm{D}}=\theta_{\mathrm{q}}+\Delta
$$

とおいてもやはり一般性を失わない。このとき

$$
\left\{\begin{array}{l}
\theta_{1 \mathrm{~A}}=\theta_{\mathrm{p}}-\Delta \\
\theta_{1 \mathrm{~B}}=\theta_{\mathrm{p}}+\Delta
\end{array}\right.
$$

となるから, 式（19）はテイラー展開一次近似を使うことで,

$$
\begin{aligned}
\tau_{\mathrm{add}} & =-\tau_{\mathrm{C}}\left(\theta_{\mathrm{p}}-\Delta\right)+\tau_{\mathrm{C}}\left(\theta_{\mathrm{p}}+\Delta\right) \\
& \simeq 2 \tau_{\mathrm{C}}^{\prime}\left(\theta_{\mathrm{p}}\right) \cdot \Delta
\end{aligned}
$$



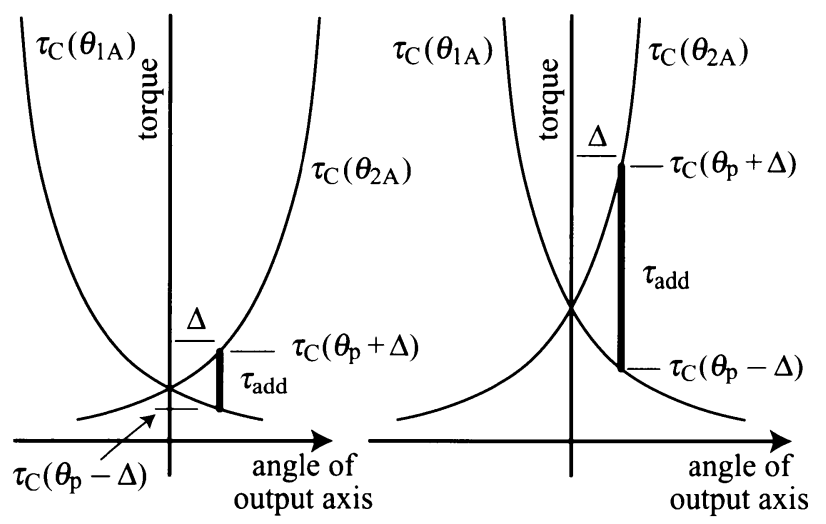

(a) $\theta_{\mathrm{p}}$ is low (low stretching)

(b) $\theta_{\mathrm{p}}$ is high (high stretching)

Fig. 7 Stiffness regulation by antagonistic output axes

と変形できる， $\tau_{\text {add }}$ と $\Delta$ の符号は同じでなければならないか ら， $\tau_{\mathrm{C}}^{\prime}$ は定義域内で正であることが求められる。すなわち， $\tau_{\mathrm{C}}$ は単調増加関数でなければならない。これは式（19）において $\tau_{\mathrm{add}}=0$ のとき, $\tau_{\mathrm{C}}\left(\theta_{\mathrm{sA}}\right)=\tau_{\mathrm{C}}\left(\theta_{\mathrm{sB}}\right)$ から, 一意に $\theta_{\mathrm{sA}}=\theta_{\mathrm{sB}}$ と決まるための条件と同じである.

式 $(24)$ から, 設定軸 $\left(\theta_{\mathrm{sA}}, \theta_{\mathrm{sB}}\right)$ に差動角 $\theta_{\mathrm{p}}$ なる变位を加 えることで, 出力軸に $2 \tau_{\mathrm{C}}^{\prime}\left(\theta_{\mathrm{p}}\right)$ なる剛性を設定でき, 式 $(21)$ から同相角 $\theta_{\mathrm{q}}$ を加えることで, 出力軸の自然角 $\left(\tau_{\mathrm{add}}=0\right.$ の ときの $\theta_{\mathrm{D}}$ の值）を $\theta_{\mathrm{q}}$ と設定できることが分かる.すなわちこ れは, 直接接続型 $\beta^{2}$-Hinge は二つの設定軸によって, 剛性と 自然角の二つを独立に設定できる関節となることを示している.

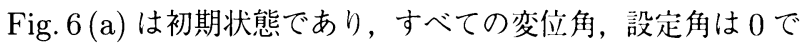
ある. 差動角 $\theta_{\mathrm{p}}$ のみを設定したのが Fig. $6(\mathrm{~b})$ である. 同相角 $\theta_{\mathrm{q}}$ を設定することは， $\beta^{2}$-Hinge 全体を回転させることに相当 するため省略した. Fig. 6 (c) は出力軸にある外力トルク $\tau_{\text {add }}$ を加えたものであり， $\tau_{\text {add }}$ に応じて $\Delta$ が決定される（Fig. 7).

なお本章では，一対の非円形歯車対を持つ $\rho^{2}$-Springにより 例示してきたが， $\tau_{\mathrm{C}}$ を適宜置き換えることで， $\rho^{2}-$ Springの非 円形歯車対が任意の段数であっても，同様にその特性を求める ことができる。

\section{6. 任意特性を実現する非円形歯車の設計法}

本章では, 任意の $\rho^{2}$-Spring の非線形出力特性や, $\beta^{2}$-Hinge の剛性設定特性から, 必要な角速度比 $G$ を求める手法を構築す る†。これにより応用に必要な特性を設計し，そこから任意形状 を持った非円形歯車を求めることが可能となる,

\section{1 設定}

$\rho^{2}$-Spring や $\beta^{2}$-Hinge に関する数式は, 角速度比 $G$ の微分. 積分や合成関数が入り組んだ形をしている。したがって求める 特性をある連続関数で与えたとしても，そこから $G$ を解析的 に求めることは一般に不可能であり, 数值計算法に拠ることに なる。

そこで, 要求する特性 $\left(\rho^{2}\right.$-Spring の場合は変位一負荷特性, 直接接続型 $\beta^{2}$-Hinge の場合は剛性設定関数 $\left.2 \tau_{\mathrm{C}}^{\prime}(\theta)\right)$ を, $n$ 区 間による 3 次スプライン補間を用いて表現したものを対象にす

\footnotetext{
†菌車の菌形は, 角速度比 $G$ から一意に決定できる。
}

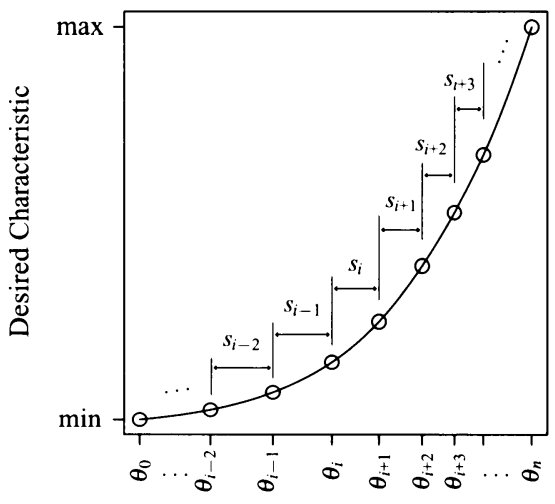

Angle of Driving Axis or Output Axis

Fig. 8 Design of arbitrarily characteristics using cubic spline curve

る (Fig. 8). すなわち $\theta_{i} \leq \theta \leq \theta_{i+1}, 0 \leq i \leq n-1$ で

$$
s(\theta)=a_{i}\left(\theta-\theta_{i}\right)^{3}+b_{i}\left(\theta-\theta_{i}\right)^{2}+c_{i}\left(\theta-\theta_{i}\right)+d_{i}
$$

である。

また同様に, $\rho^{2}$-Spring の弾性源の変位一負荷特性 $\tau_{\mathrm{u}}$ も, $m$ 区間による 3 次スプライン補間によって表現されているもの とする。これは変位一負荷特性が明確でない弾性源を使用する 際に，実験によって得られた特性を使って非円形歯車の設計を 行うとき, 適用しやすい方法である. 変位一負荷関数 $\tau_{\mathrm{u}}$ が区間 $\left[0, \theta_{\mathrm{u}, \max }\right]$ で定義されているとき, $\theta_{i} \leq \theta \leq \theta_{i+1}$ で

$$
\tau_{\mathrm{u}}(\theta)=a_{\mathrm{u}, i}\left(\theta-\theta_{i}\right)^{3}+b_{\mathrm{u}, i}\left(\theta-\theta_{i}\right)^{2}+c_{\mathrm{u}, i}\left(\theta-\theta_{i}\right)+d_{\mathrm{u}, i}
$$

と表される。ここで $\theta_{0}=0, \theta_{m}=\theta_{\mathrm{u}, \max }$ である. 単純な線 形バネのときには, $m=1, a_{\mathrm{u}, 0}=0, b_{\mathrm{u}, 0}=0, c_{\mathrm{u}, 0}=k$, $d_{\mathrm{u}, 0}=0$ とすればよい.

3 次スプライン補間は第 2 次導関数まで連続であり, 区間を細 かく切ることで補間精度を上げることができるので, 高次項を 使用する多項式近似と比較して, 数值計算の精度上有利である.

まず任意の変位一負荷特性を持つ $\rho^{2}$-Spring の設計法につい て説明する，直接接続型 $\beta^{2}$-Hinge の設計法は $\rho^{2}$-Spring の設 計法と共通する部分が多いため, 紙面の都合上, 簡潔に説明す る. 付録 B には, 本章で提案する手法による設計例を示す.

\section{$6.2 \rho^{2}$-Spring $の$ 設計手法}

非円形歯車のピッチ曲線など, 非円形歯車の特性はすべて角 速度比 $G_{1,2 n}(\theta)$ によって記述されている. そこで式（13）の左 辺を, 設計したスプライン関数（式 $(25))$ に置き換え, この式 を満たす角速度比 $G_{1,2 n}(\theta)$ を求めることを目的とする。 そこで $G_{1,2 n}(\theta)$ に関する常微分方程式を導出し, 数值的に解を得る手 法を提案する.

なお本手法では, Fig. 5 に示す $n$ 個の非円形歯車対の初段と 最終段の間の角速度比 $G_{1,2 n}(\theta)$ を対象とするため, 個々の非円 形歯車対の角速度比 $G_{m, m+1}(\theta)$ は式（15）を解いて別に求め る必要がある。一対の非円形歯車対のみの利用であればその必 
要ない.

下記の手法によって $G_{1,2 n}(\theta)$ を求めた際, ピッチ曲線の傾斜 角に関する条件式（8）を満たさないことや， $\int_{0}^{\theta_{1 \mathrm{e}}} G_{1,2 n}(\theta) \mathrm{d} \theta$ が $2 \pi$ を超えるなど，現実には歯車として成立しないものが解と して得られることがある，そのようなときは，例えば弾性源の 変位-負荷特性 $\tau_{\mathbf{u}}$ に変更を加えるなどの試行錯誤によって，奏 現可能な解へ収束させる操作が必要となる。

6.2 .1 常微分方程式

必要な変位一負荷特性は, 式（25）において与えられている. ただし， $\theta_{0}=0, \theta_{n}=\theta_{1 \mathrm{e}}$ である。式 (13)より，

$$
\begin{gathered}
G_{1,2 n}(\theta) \cdot \tau_{\mathrm{u}}\left(T_{1,2 n}(\theta)\right)=s(\theta) \\
\therefore G_{1,2 n}(\theta) \cdot \tau_{\mathrm{u}}\left(\int_{0}^{\theta} G_{1,2 n}(\theta) \mathrm{d} \theta\right)=s(\theta)
\end{gathered}
$$

から $G_{1,2 n}(\theta)$ を求める問題となる.

$\tau_{\mathrm{u}}$ の逆関数 $\operatorname{inv} \tau_{\mathrm{u}}(\tau)$ を定義（Fig. 9 参照）し，角速度比は 常に正であることを利用すると，以下のように変形できる。

$$
\int_{0}^{\theta} G_{1,2 n}(\theta) \mathrm{d} \theta=\operatorname{inv} \tau_{\mathrm{u}}\left(\frac{s(\theta)}{G_{1,2 n}(\theta)}\right)
$$

合成関数の微分より，

$G_{1,2 n}(\theta)=\operatorname{inv} \tau_{\mathrm{u}}^{\prime}\left(\frac{s(\theta)}{G_{1,2 n}(\theta)}\right) \frac{s^{\prime}(\theta) G_{1,2 n}(\theta)-s(\theta) G_{1,2 n}^{\prime}(\theta)}{\left(G_{1,2 n}(\theta)\right)^{2}}$

$\therefore G_{1,2 n}^{\prime}(\theta)=\frac{1}{s(\theta)}\left(s^{\prime}(\theta) G_{1,2 n}(\theta)-\frac{G_{1,2 n}(\theta)^{3}}{\operatorname{inv} \tau_{u}^{\prime}\left(\frac{s(\theta)}{G_{1,2 n}(\theta)}\right)}\right)$

となる.

6. 2.2 初期值 $G_{1.2 n}(0)$

式（27）に $\theta=0$ を代入することで

$$
G_{1,2 n}(0)=\frac{s(0)}{\tau_{\mathrm{u}}(0)}
$$

と求められるが, 本式には次のような問題がある. まず $s(0)=0$ のとき，すなわち初張力を持たない $\rho^{2}$-Spring を設計した際に は $G_{1,2 n}(0)=0$ となり，このような非円形歯車を実現すること はできない†.さらに $\tau_{\mathrm{u}}(0)=0$ のとき，すなわち $\rho^{2}$-Springの 弾性源が初張力を持たないときは $G_{1,2 n}(0)=\infty$ となり, やは り不可能である。したがって上式は, 初張力を持つ $\rho^{2}-$ Spring を, 初張力を持つ弾性源を使って構成するときのみである.

そこで，初張力を持たない $\rho^{2}$-Spring 初張力を持たない弾性 源で構成するとき叶，すなわち $s(0)=0\left(\therefore d_{0}=0\right), \tau_{\mathrm{u}}(0)=0$ のときの, $G_{1,2 n}(\theta)$ の初期值を別に求める. 式 $(29)$ に $\theta=0$ を代入すると

†これは，減速比０の㐘車であることを示している．

††压縮バネを弾性源に用いる場合に相当する。
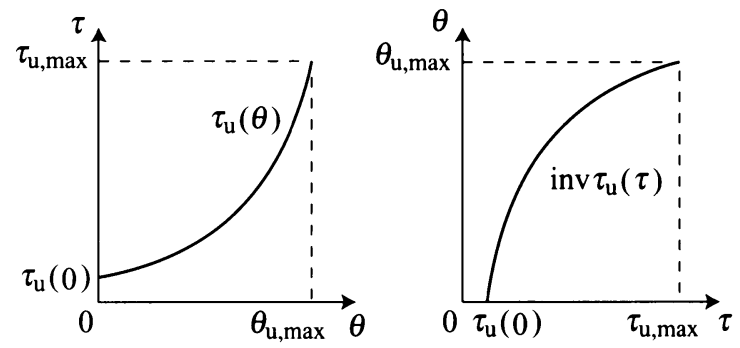

Fig. 9 Inverse function: $\operatorname{inv} \tau_{\mathbf{u}}(\theta)$
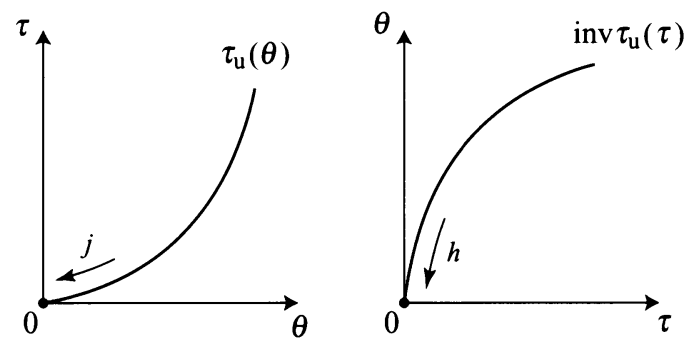

Fig. 10 Relationship between $h$ and $j$ under non-initial-force

$$
\begin{aligned}
& G_{1,2 n}(0)=\operatorname{inv} \tau_{u}^{\prime}\left(\frac{s(0)}{G_{1,2 n}(0)}\right) \frac{s^{\prime}(0) G_{1,2 n}(0)-s(0) G_{1,2 n}^{\prime}(0)}{\left(G_{1,2 n}(0)\right)^{2}} \\
& \therefore G_{1,2 n}(0)=\sqrt{\operatorname{inv} \tau_{u}^{\prime}(0) \cdot s^{\prime}(0)} \\
&=\sqrt{\operatorname{inv} \tau_{u}^{\prime}(0) \cdot c_{0}}
\end{aligned}
$$

となる。ここで $\operatorname{inv} \tau_{\mathrm{u}}^{\prime}(0)$ を極限を用いて求めると，

$$
\begin{aligned}
\operatorname{inv} \tau_{\mathrm{u}}^{\prime}(0) & =\lim _{h \rightarrow 0}\left(\left.\frac{\mathrm{d}}{\mathrm{d} t} \operatorname{inv} \tau_{\mathrm{u}}(t)\right|_{t=h}\right) \\
& =\lim _{j \rightarrow 0}\left(\left.\frac{1}{\frac{\mathrm{d}}{\mathrm{d} \theta} \tau_{\mathrm{u}}(\theta)}\right|_{\theta=j}\right)
\end{aligned}
$$

$$
\because h \rightarrow 0 \text { で } j \rightarrow 0 \text { (Fig. 10) }
$$

となるが, $\theta$ が十分 0 に近いとき, $\frac{\mathrm{d}}{\mathrm{d} \theta} \tau_{\mathrm{u}}(\theta)=\frac{\mathrm{d}}{\mathrm{d} \theta} \tau_{\mathrm{u}, 0}(\theta)$ $=3 a_{\mathrm{u}, 0} \theta^{2}+2 b_{\mathrm{u}, 0} \theta+c_{\mathrm{u}, 0}$ となるから,

$$
\operatorname{inv} \tau_{\mathrm{u}}^{\prime}(0)=\lim _{j \rightarrow 0} \frac{1}{3 a_{\mathrm{u}, 0} j^{2}+2 b_{\mathrm{u}, 0} j+c_{\mathrm{u}, 0}}=\frac{1}{c_{\mathrm{u}, 0}}
$$

と求められる $\left(c_{\mathrm{u}, 0}\right.$ が 0 となる，もしくは非常に 0 に近い弾性 源を取り扱うときには注意が必要である。そのような場合には， 弾性源に初張力を与えるなどの対策をすることが求められる).

以上をまとめると, 初張力を持たないときの初期值 $G_{1,2 n}(0)$ は, 次のように求められる.

$$
G_{1,2 n}(0)=\sqrt{\frac{c_{0}}{c_{\mathrm{u}, 0}}}
$$

6.2 .3 微分值の初期值 $G_{1,2 n}^{\prime}(0)$

本項も, 前項と同様に初張力の有無によって導出が異なる.

(1) 初張力があるとき

式 (30) に $\theta=0$ を代入すると, 
$G_{1.2 n}^{\prime}(0)=\frac{1}{s(0)}\left(s^{\prime}(0) G_{1,2 n}(0)-\frac{G_{1,2 n}(0)^{3}}{\operatorname{inv} \tau_{\mathbf{u}}^{\prime}\left(\frac{s(0)}{G_{1,2 n}(0)}\right)}\right)$

となる。

ここで $\operatorname{inv} \tau_{\mathrm{u}}^{\prime} \frac{s(0)}{G_{1.2 n}(0)}$ を，極限により求める. 式 (31) より $\frac{s(0)}{G_{1,2 n}(0)}=\tau_{\text {u1 }}(0)$ だから,

$$
\begin{aligned}
& \operatorname{inv} \tau_{\mathbf{u}}^{\prime}\left(\tau_{\mathrm{u}}(0)\right)=\lim _{h \rightarrow \tau_{\mathrm{u}}(0)}\left(\left.\frac{\mathrm{d}}{\mathrm{d} t} \operatorname{inv} \tau_{\mathrm{u}}(t)\right|_{t=h}\right) \\
&=\lim _{j \rightarrow 0} \frac{1}{\left.\frac{\mathrm{d}}{\mathrm{d} \theta} \tau_{\mathbf{u}}(\theta)\right|_{\theta=j}} \\
& \because h \rightarrow \tau_{\mathrm{u}}(0) \text { で } j \rightarrow 0(\text { Fig. 11) }
\end{aligned}
$$

となるが, $\theta$ が十分 0 に近いとき, $\frac{\mathrm{d}}{\mathrm{d} \theta} \tau_{\mathrm{u}}(\theta)=\frac{\mathrm{d}}{\mathrm{d} \theta} \tau_{\mathrm{u}, 0}(\theta)$ $=3 a_{\mathrm{u}, 0} \theta^{2}+2 b_{\mathrm{u}, 0} \theta+c_{\mathrm{u}, 0}$ となるから,

$$
\operatorname{inv} \tau_{\mathbf{u}}^{\prime}\left(\tau_{\mathrm{u}}(0)\right)=\lim _{j \rightarrow 0} \frac{1}{3 a_{\mathrm{u}, 0} j^{2}+2 b_{\mathrm{u}, 0} j+c_{\mathrm{u}, 0}}=\frac{1}{c_{\mathrm{u}, 0}}
$$

と求められる， $c_{\mathrm{u}, 0}=\infty$ となることは現実にはない.

具体的に書き直すと, 次の通りである.

$$
G_{1,2 n}^{\prime}(0)=\frac{1}{d_{0}}\left(c_{0} \cdot G_{1,2 n}(0)-c_{\mathrm{u}, 0} \cdot G_{1,2 n}(0)^{3}\right)
$$

（2）初張力がないとき

初張力がないとは, $s(0)=0\left(\therefore d_{0}=0\right), \tau_{\mathrm{u}}(0)=0$ のとき である.このとき式 $(30)$ に $\theta=0$ を代入すると， 0 で除算す ることになるのですぐには求められない，そこで極限によって $G_{1,2 n}^{\prime}(0)$ を求める.すなわち

$$
\begin{aligned}
& G_{1,2 n}^{\prime}(0) \\
& \quad=\lim _{h \rightarrow 0}\left\{\frac{1}{s(h)}\left(s^{\prime}(h) G_{1,2 n}(h)-\frac{G_{1,2 n}(h)^{3}}{\operatorname{inv} \tau_{\mathbf{u}}^{\prime}\left(\frac{s(h)}{G_{1,2 n}(h)}\right)}\right)\right\}
\end{aligned}
$$

である。ここで $h$ は十分 0 に近いから 1 次近似を利用すると， 上式は

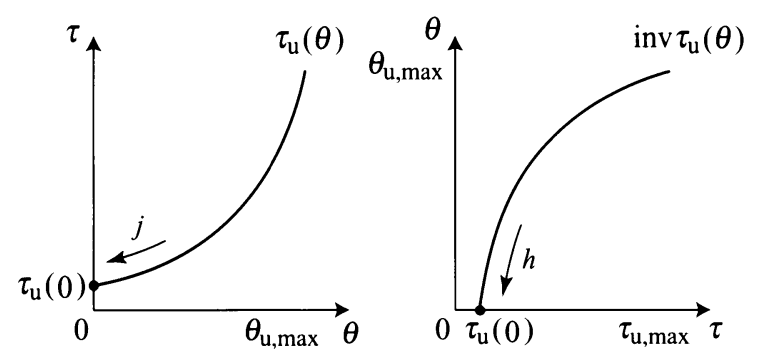

Fig. 11 Relation between $h$ and $j$ under initial force

$$
\begin{gathered}
\lim _{h \rightarrow 0}\left\{\frac { 1 } { c _ { 0 } h + O } \left(2 b_{0} G(0) h+c_{0}\left(G(0)+G^{\prime}(0) h\right)+O\right.\right. \\
\left.\left.-\frac{G(0)^{3}+3 G(0)^{2} G^{\prime}(0) h+O}{\operatorname{inv} \tau_{\mathbf{u}}^{\prime}\left(\frac{s(h)}{G(h)}\right)}\right)\right\}
\end{gathered}
$$

と変形できる $\left(G\right.$ は $G_{1,2 n}$ を, O は $O\left(h^{2}\right)$ を略記したもので ある)。ここで極限を取ることで $\mathrm{O}$ を無視し，式（33）の結果 を用いると，

$$
2 b_{0} \sqrt{\frac{1}{c_{0} c_{\mathrm{u}, 0}}}-2 G_{1,2 n}^{\prime}(0)
$$

となるから, 以下のように求められる。

$$
G_{1,2 n}^{\prime}(0)=\frac{2}{3} b_{0}\left(c_{0} c_{\mathrm{u}, 0}\right)^{-\frac{1}{2}}
$$

\section{2 .4 初期値のまとめ}

初張力のある弾性源を用いて, 初張力のある $\rho^{2}$-Spring を構 成するとき。

$$
\left\{\begin{array}{l}
G_{1.2 n}(0)=\frac{s(0)}{\tau_{\mathrm{u}}(0)}=\frac{d_{0}}{d_{\mathrm{u}, 0}} \\
G_{1,2 n}^{\prime}(0)=\frac{c_{0} \cdot G_{1,2 n}(0)-c_{\mathrm{u}, 0} \cdot G_{1,2 n}(0)^{3}}{d_{0}}
\end{array}\right.
$$

(38b)

初張力のない弾性源を用いて, 初張力のない $\rho^{2}$-Spring を構 成するとき。

$$
\left\{\begin{aligned}
G_{1,2 n}(0) & =\sqrt{\frac{c_{0}}{c_{\mathrm{u}, 0}}} \\
G_{1,2 n}^{\prime}(0) & =\frac{2}{3} b_{0}\left(c_{0} c_{\mathrm{u}, 0}\right)^{-\frac{1}{2}}
\end{aligned}\right.
$$

初張力のない弾性源によって初張力のある $\rho^{2}$-Spring を構成 すること，もしくは，初張力のある弾性源によって初張力のな い $\rho^{2}$-Spring を構成することは, 対応する非円形歯車が機械要 素として成立しないため, 不可能である.

\subsection{5 $\rho^{2}$-Spring の弾性源が単純な線形バネのとき}

式（26）において $m=1, a_{\mathrm{u}, 0}=b_{\mathrm{u}, 0}=d_{\mathrm{u}, 0}=0$, $c_{\mathrm{u}, 0}=k>0$ となるとき, すなわち

$$
\tau_{\mathrm{u}}(\theta)=k \theta
$$

となるときである． 6.1 節では $\tau_{\mathrm{u}}$ の係数は決定されていること を前提にしていたが，ここではその必要はない。逆に $k$ を未定 のまま計算し，最後に角度範囲条件（式 $(7))$ 等から $k$ を決定 することが可能である。

常微分方程式は, $\operatorname{inv} \tau_{\mathrm{u}}^{\prime}(t)=1 / k$ となることから，

$$
G_{1,2 n}^{\prime}(\theta)=\frac{1}{s(\theta)}\left(s^{\prime}(\theta) G_{1,2 n}(\theta)-\frac{G_{1,2 n}(\theta)^{3}}{1 / k}\right)
$$

となる.ここで

$$
\hat{G}_{1,2 \mathrm{n}}(\theta)=\sqrt{k} G_{1,2 n}(\theta)
$$


なる変換を用いることで, 次のように変形できる.

$$
\hat{G}_{1,2 \mathrm{n}}^{\prime}(\theta)=\frac{s^{\prime}(\theta) \hat{G}_{1,2 \mathrm{n}}(\theta)-\hat{G}_{1,2 \mathrm{n}}(\theta)^{3}}{s(\theta)}
$$

前項における「初張力なし」の結果に代入することで，

$$
\begin{aligned}
\hat{G}_{1,2 \mathrm{n}}(0) & =\sqrt{c_{0}} \\
\hat{G}_{1,2 \mathrm{n}}^{\prime}(0) & =\frac{2}{3} \frac{b_{0}}{\sqrt{c_{0}}}
\end{aligned}
$$

と求められる．これにより $k$ の值が未定であっても，常微分方 程式を数值的に解くことができる.

(1) 未定係数 $k$ の決定

すでに $\hat{G}_{1,2 \mathrm{n}}(\theta)$ が求まっているとする.式 (7) に $\hat{G}_{1,2 \mathrm{n}}(\theta)$ を代入すると，

$$
\theta_{2 n \mathrm{e}}=\int_{0}^{\theta_{1 \mathrm{e}}} \frac{1}{\sqrt{k}} \hat{G}_{1,2 \mathrm{n}}(\theta) \mathrm{d} \theta=\frac{1}{\sqrt{k}} \int_{0}^{\theta_{1 \mathrm{e}}} \hat{G}_{1,2 \mathrm{n}}(\theta) \mathrm{d} \theta
$$

となり, バネ係数 $k$ と $\rho^{2}$-Spring の最終対の被動軸の最大回転 角 $\theta_{2 n \mathrm{e}}$ は互いに従属となっている。これより，使用できる弾性 源のバ六係数と最大回転角 $\theta_{2 n \mathrm{e}}$ の関係より，より適当なものに 調整することができる。

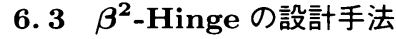

本節では 5 章で示した，直接接続型 $\beta^{2}$-Hinge を対象とした 設計手法を示す。

直接接続型 $\beta^{2}$-Hinge の出力トルクは式 (24) で示される. 本 節ではこの $2 \tau_{\mathrm{C}}^{\prime}\left(\theta_{\mathrm{p}}\right)$ を設計対象とする。すなわち， $\rho^{2}$-Spring のときと同じく, 3 次スプライン補間多項式 $s(\theta)$ （式 $(25)$ ）を 使い，以下のような特性を表現する $G_{1,2 n}(\theta)$ を求める問題と なる。

$$
\begin{aligned}
2 \tau_{\mathrm{C}}^{\prime}(\theta) & =2\left[G_{1,2 n}(\theta) \cdot \tau_{\mathrm{u}}\left(\int_{0}^{\theta} G_{1,2 n}(\theta) \mathrm{d} \theta\right)\right]^{\prime} \\
& =s(\theta)
\end{aligned}
$$

しかし，これだけでは問題設定としては十分ではない.その理 由は以下の通りである。 ある定数 $p_{1}, p_{2}$ を用いて二つの関数 $\tau_{\mathrm{c}}(\theta)+p_{1}, \tau_{\mathrm{c}}(\theta)+p_{2}$ を作る. 当然ながらこの二つの関数は同 一の 1 階微分 $\tau_{\mathrm{c}}^{\prime}(\theta)$ を持つため, $\rho^{2}$-Spring の变位一負荷関数が $\tau_{\mathrm{c}}(\theta)+p_{1}, \tau_{\mathrm{c}}(\theta)+p_{2}$ のどちらであっても，それにより構成さ れる $\beta^{2}$-Hinge の特性は同じことになる (Fig. 12 参照)。すな わち，式（45）を満たす $\tau_{\mathrm{C}}(\theta)$ は，初期值に制約がないため無 数に存在することとなり, 式（45）だけでは解を得ることはで きない.

そこで $\tau_{\mathrm{C}}(\theta)$ の初期值 $\tau_{\mathrm{C}}(0)$ を $\epsilon$ 置くことにし, 式 (45) の両辺を区間 $[0, \theta]$ で積分すると以下のようになる。

$$
\tau_{\mathrm{C}}(\theta)-\epsilon=\frac{1}{2} \int_{0}^{\theta} s(\theta) \mathrm{d} \theta
$$

式（13）より

$$
G_{1,2 n}(\theta) \tau_{\mathrm{u}}\left(\int_{0}^{\theta} G_{1,2 n}(\theta) \mathrm{d} \theta\right)=\frac{1}{2} \int_{0}^{\theta} s(\theta) \mathrm{d} \theta+\epsilon
$$

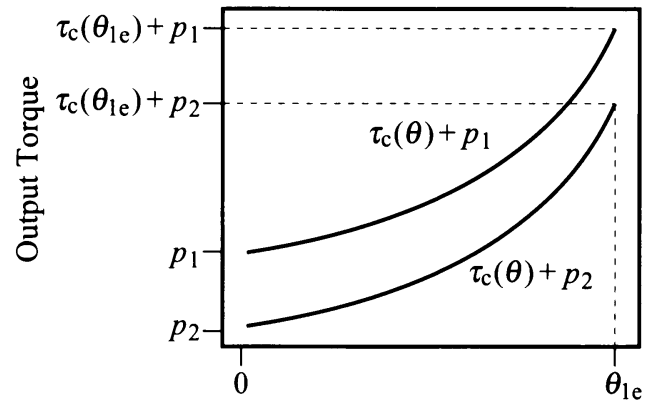

Angle of $\rho^{2}$-Spring Driving Shaft

Fig. 12 Two $\rho^{2}$-Springs having same first derivative

上式右辺を $S(\theta)$ と置くと，

$$
G_{1,2 n}(\theta) \tau_{\mathrm{u}}\left(\int_{0}^{\theta} G_{1,2 n}(\theta) \mathrm{d} \theta\right)=S(\theta)
$$

となり，これが解くべき問題となる。あとの手順はほぼ前節と 同じであるので，導かれる結果のみを示すにとどめる，すなわ ち, $\epsilon=0$ のときは「初張力なし」の $\rho^{2}$-Spring の, $\epsilon>0$ のと きは「初張力あり」の問題と同じように取り扱えばよい.

常微分方程式は, 式 (27) の $s$ を $S$ 一置き換えることで,

$$
G_{1,2 n}^{\prime}(\theta)=\frac{1}{S(\theta)}\left(S^{\prime}(\theta) G_{1,2 n}(\theta)-\frac{G_{1,2 n}(\theta)^{3}}{\operatorname{inv} \tau_{\mathrm{u}}^{\prime}\left(\frac{S(\theta)}{G_{1,2 n}(\theta)}\right)}\right)
$$

と求められる。初期值も同様に求められて，初張力がある場合は

$$
\left\{\begin{array}{l}
G_{1,2 n}(0)=\frac{S(0)}{\tau_{\mathrm{u}}(0)}=\frac{\epsilon}{d_{\mathrm{u}, 0}} \\
G_{1,2 n}^{\prime}(0) \\
\quad=\frac{1}{S(0)}\left(S^{\prime}(0) G_{1,2 n}(0)-\frac{G_{1,2 n}(0)^{3}}{\operatorname{inv} \tau_{\mathrm{u}}^{\prime}\left(\frac{S(0)}{G_{1,2 n}(0)}\right)}\right)
\end{array}\right.
$$

となり，初張力がない場合は

$$
\left\{\begin{aligned}
G_{1,2 n}(0) & =\sqrt{\frac{d_{0}}{2 c_{\mathrm{u}, 0}}} \\
G_{1,2 n}^{\prime}(0) & =\frac{1}{3} c_{0} \sqrt{\frac{1}{2 d_{0} c_{\mathrm{u}, 0}}}
\end{aligned}\right.
$$

である.

\section{7. 実験}

理論の検証のために試作を行い実験を行った。

\section{1 直接駆動型 $\boldsymbol{\beta}^{2}$-Hinge}

Fig. 13 は製作した試作機の写真である. Fig. 14 は試作機 の内部構造であり， $\rho^{2}$-Spring が内蔵されている。試作機はそ れぞれ同一の $\rho^{2}$-Spring を内蔵した二つの要素（白・黒）に分 


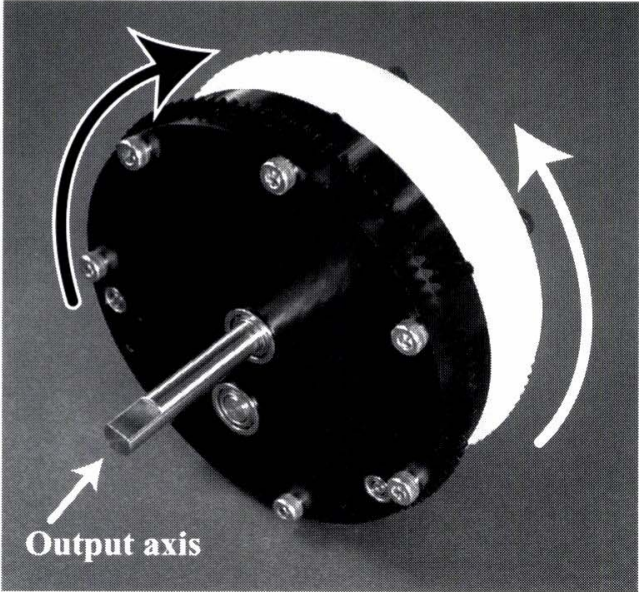

Fig. 13 The prototype of direct connecting $\beta^{2}$-Hinge

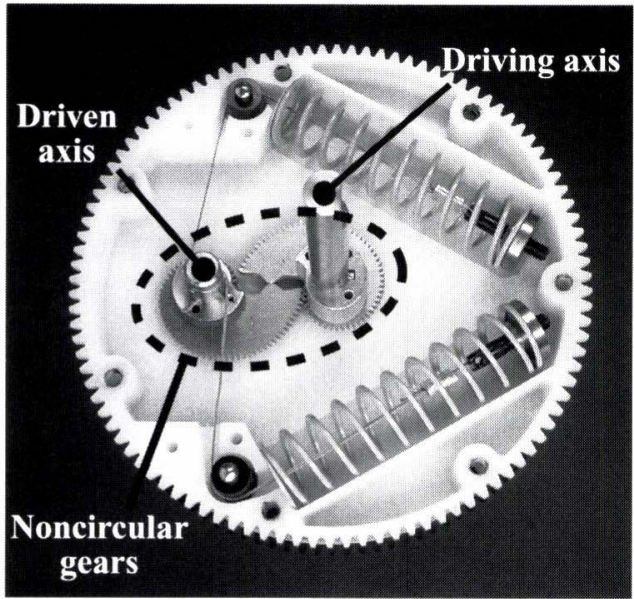

Fig. 14 Inside mechanism of $\beta^{2}$-Hinge

けられこれが出力軸に互いに拮抗するように接続されている. Fig. 13 の図中の矢印の様に“ねじこむ”ことが，5章の設定軸 に差動角を与えていることに相当するため, 出力軸での剛性を 設定することができる.

7.1 .1 内部構造

非円形歯車として, 対数らせん歯車を用いた。こ扎は駆動歯車 と被動歯車を同一の形状にすることができるためである。なお対 数らせん歯車については付録に詳細を示す. 主要諸元を Table 1 に示す.

7.1 .2 実験結果 : $\rho^{2}$-Spring

一つの $\rho^{2}$-Spring の变位一負荷特性を測定した。結果はFig. 15 である。点が実測值で実線が理論值である。ただし $\rho^{2}$-Spring が内部に持つ摩擦によって，実測値は一意に決まらずある範囲 に分布するため, その平均值を用いた。 Fig. 15 より, 非常によ く一致していることが分かる。これより $\rho^{2}$-Springを用いるこ とで, 非線形性の強い变位一負荷特性であっても, 実現が可能で あることが分かる.

\section{1 .3 実験結果： $\beta^{2}$-Hinge}

設定角を 6 段階に取り，それぞれにおいて変位一負荷特性を 計測した $($ Fig. 16)。丸点が実測值であり，実線が理論值であ
Table 1 Specifications of the prototype of direct connecting $\beta^{2}$-Hinge

\begin{tabular}{cc}
\hline$R_{1}$ & $A \exp \left(t \theta_{1}\right)$ \\
$R_{2}$ & $(C-A) \exp \left(-t \theta_{2}\right)$ \\
$G$ & $\frac{A \exp \left(t \theta_{1}\right)}{C-A \exp \left(t \theta_{1}\right)}$ \\
$\theta_{1}$ & $0 \ldots 345[\mathrm{deg}]$ \\
$\theta_{2}$ & $0 \ldots 345[\mathrm{deg}]$ \\
$C$ & $20.0[\mathrm{~mm}]$ \\
$A$ & $4.25[\mathrm{~mm}]$ \\
$t$ & 0.2173 \\
Module & 0.305 \\
Material (gear) & $\mathrm{C} 3713 \mathrm{P}$ \\
Size (shell) & $\phi 83[\mathrm{~mm}] \times \mathrm{W} 32[\mathrm{~mm}]$ \\
Material (shell) & POM
\end{tabular}

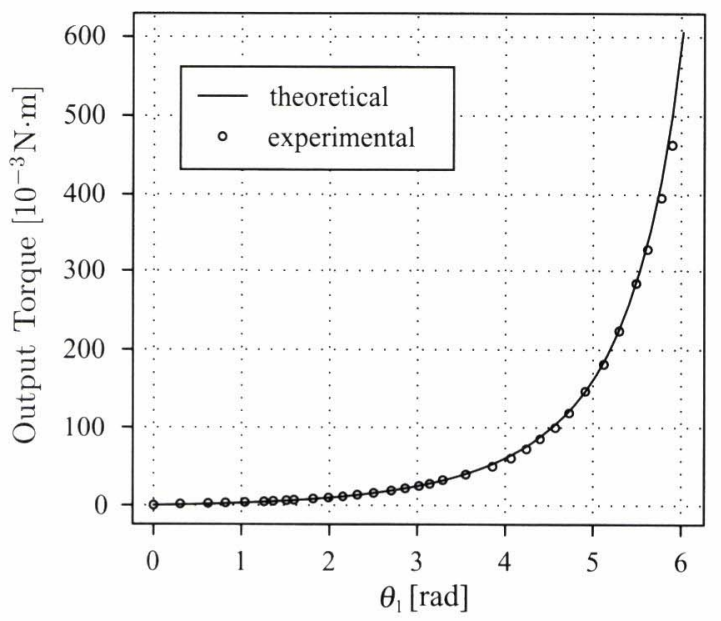

Fig. 15 Nonlinear torsion profile of $\beta^{2}$-Hinge

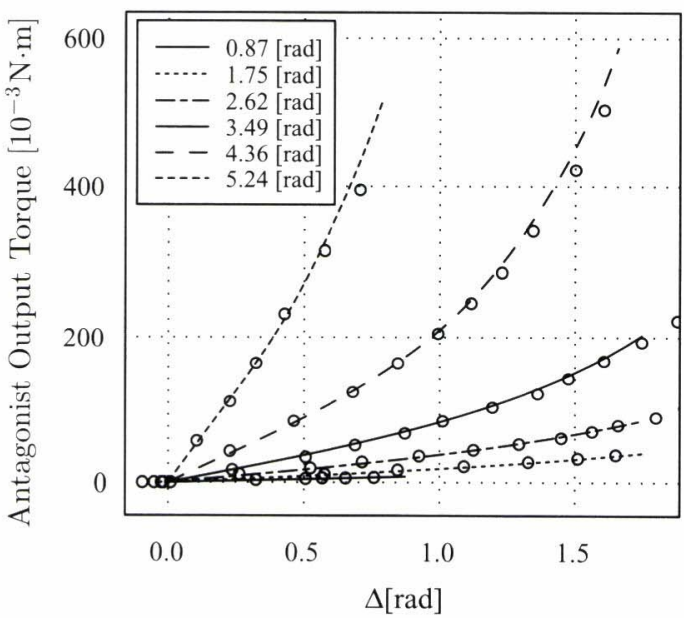

Fig. 16 Variable stiffness of $\beta^{2}$-Hinge

る。 $\beta^{2}$-Hinge の内部摩擦による䛊差は, $\rho^{2}$-Spring のときと同 様の処理をした．負荷がないときに変位 $\Delta$ が 0 からずれるもの が確認されたが, それ以外は実測值と理論值はよく一致してい る。この実験では, 最低の剛性值（設定角 $0.87[\mathrm{rad}]$ ） と最大の 㴊性值（設定角 $5.24[\mathrm{rad}] ）$ の比は 61 倍である。
8. 結
論

非円形歯車の不等速運動と，バネに代表される機械的な弾性 
要素を組み合わせることで，小型で確実に動作し任意の変位一 負荷特性を持たせることのできる非線形弾性要素 $\rho^{2}$-Spring を 提案した。 $\rho^{2}$-Spring の駆動軸同士を怙抗するように直接接続 させることにより，拮抗駆動型可变剛性関節である直接接続型 $\beta^{2}$-Hinge を提案しその特性を解析的に明らかにした。ささらに， 任意特性を持つ $\rho^{2}$-Spring と $\beta^{2}$-Hinge を実現する非円形歯車 の設計手法を示した.

今後の課題として，高トルクを負荷させたときの非円形歯車 の摩擦の影響を調べること, 可変弾性要素を持つロボットの効 率的な制御手法の確立, さらにより具体的なアプリケーション への適用を行っていく必要がある.

謝 辞 本研究は文部科学省科学研究費 (No. 16650036) の 支援のもとで行われた.

\section{参 考 文 献}

[1] 岡田昌史：“人間らしい柔らかな動きと駆動機構”, 日本ロボット学会 誌, vol.17, no.6, pp.782-785, 1999.

[2] R. Shadmehr and M.A. Arbib: "A mathmatical analysis of the force-stiffness characteristics of muscles and the role of reflexes in control of a single joint system," Biological Cybernetics, vol.66, pp.463-477, 1992.

[3] K.F. Laurin-Kovitz, J.E. Colkgate and S.D.R. Carnes: "Design of Components for Programmable Passive Impedance," Proceedings of International Conference on Robotics and Automation, pp.1476-1481, 1991.

[4] J.W. Hurst, J.E. Chestnutt and A.A. Rizzi: "An Actuator with Physically Variable Stiffness for Highly Dynamic Legged Locomotion," Proceedings of the 2004 IEEE International Conference on Robotics and Automation, vol.5, pp.4662-4667.

[5] 森田寿郎, 菅野重樹：“メカニカルソフトネスとコンプライアンス調 整”, 日本ロボット学会誌, vol.17, no.6, pp.790-794, 1999.

[6] 森田寿郎, 富田信義, 植田武男, 菅野重樹：“関節の機械インピーダ ンスを調節可能な力制御ロボットアームの開発”, 日本ロボット学会 誌, vol.16, no.7, pp.1001-1006, 1998.

[7] 林原靖男, 箱木北斗, 渡辺浩太郎： “剛性可变機構を用いたりハビリ 用 CPM 装置の開発”, 日本機械学会ロボティクス・メカトロニクス 講演会'04 予稿集, $1 \mathrm{~A} 1-\mathrm{H}-77$ (CD-ROM), 2004.

[8] 小金澤鋼一, 山崎政道, 石川夏男: “剛性可変機能を有する拮抗筋 型腱駆動システムとその制御”, 日本ロボット学会誌, vol.18, no.7, pp.1003-1010, 2000

[9] 兵頭和人, 小林博明: “非線形バネ要素を持つ腱制御手首機構の研究”, 日本ロボット学会誌, vol.11, no.8, pp.1244-1251, 1993.

[10] N.P. Chironis: GEAR DESIGN AND APPLICATION. pp.158 167, McGraw-Hill, 1967.

[11] 香取英男：非円形歯車の設計・製作と忍用. 日刊工業新聞社, 2001.

[12] D.B. Dooner and A.A. Seireg: THE KINEMATIC GEOMETRY OF GEARING. Wiley-Interscience, 1995.

付録 A. 対数らせん歯車 (Logarithmic Spiral Gear)

本付録では, ピッチ曲線が対数らせんとなる対数らせん歯車 について，その特徴と設計手法を示す．变数はすべて Fig. 4 お よび第 3 章と共通である。

付録 A.1 ピッチ曲線

対数らせん菌車とは, ピッチ曲線が $A \exp \left(t \theta_{1}\right)$ と表される歯 車のことを指す.ただし $A, t$ は適当な定数である.いま駆動 歯車を

$$
R_{1}\left(\theta_{1}\right)=A \exp \left(t \theta_{1}\right)
$$

と定義すると, 角速度比 $G$ は

$$
G\left(\theta_{1}\right)=\frac{A \exp \left(t \theta_{1}\right)}{C-A \exp \left(t \theta_{1}\right)}
$$

となる。このとき, 角速度比の定義式（6）ょり

$$
\begin{aligned}
\theta_{2} & =\int_{0}^{\theta_{1}} G\left(\theta_{1}\right) \mathrm{d} \theta_{1} \\
& =\frac{1}{t}\left\{\log (C-A)-\log \left(C-A \exp \left(t \theta_{1}\right)\right)\right\}
\end{aligned}
$$

となるから，

$$
\theta_{2}=\log \left(C-A \exp \left(t \theta_{1}\right)\right)=\log (C-A)-t \theta_{2}
$$

である.したがって $R_{2}$ は

$$
\begin{aligned}
R_{2}\left(\theta_{2}\right) & =C-R_{1}\left(\theta_{1}\right)=C-A \exp \left(t \theta_{1}\right) \\
& =(C-A) \exp \left(-t \theta_{2}\right) \because \text { 式 (A.4) }
\end{aligned}
$$

となり, 被動歯車も対数らせん歯車となる.

傾斜角 $\phi$ は式 (8) 加簡単に

$$
\phi=\tan ^{-1}(t)=\text { const. }
$$

と求められる。傾斜角が一定であるということは歯車のかみ合 い角を一定にできることを示しており，安定した動作のために 重要な特徴となる。

付録 A.2 駆動・被動歯車のピッチ形状が同一となる条件

対数らせん歯車は，駆動歯車と被動歯車の形状を同一にする ことが可能である。このことは応用上コストの低隇に直結する ので, 重要な非円形㐘車の形状であるといえる.

ピッチ形状が同一であるためには, 駆動歯車と被動歯車の回 転角範囲が同一であることが必要である，すなわち式 (1a)，式 (1b)において $\theta_{1 \mathrm{e}}$ と $\theta_{2 \mathrm{e}}$ を同一の $\theta_{\mathrm{e}}$ と置けるので, 式 (A.3) より,

$$
\begin{gathered}
\theta_{\mathrm{e}}=\frac{1}{t}\left\{\log (C-A)-\log \left(C-A \exp \left(t \theta_{\mathrm{e}}\right)\right\}\right. \\
\rightleftharpoons-A \exp \left(t \theta_{\mathrm{f}}\right)^{2}+C \exp \left(t \theta_{\mathrm{f}}\right)-(C-A)=0 \\
\therefore \exp \left(t \theta_{\mathrm{f}}\right)=\frac{-C \pm \sqrt{C^{2}-4 A(C-A)}}{-2 A}=\frac{C-A}{A} \text { or } 1
\end{gathered}
$$

となるが, $t, \theta_{\mathrm{f}}$ はそれぞれ 0 ではないから，

$$
\exp \left(t \theta_{\mathrm{f}}\right)=\frac{C-A}{A}
$$

が，回転角が同一となるための条件となる.

いま $\theta_{2}=-\theta_{3}+\theta_{\mathrm{e}}$ とおくと式（A.5）より，

$$
\begin{aligned}
R_{2} & =(C-A) \exp \left(-t\left(-\theta_{3}+\theta_{\mathrm{f}}\right)\right) \\
& =(C-A) \exp \left(t \theta_{3}\right) \cdot \exp \left(-t \theta_{\mathrm{f}}\right) \\
& =A \exp \left(t \theta_{3}\right) \quad \because \text { 式 }(\mathrm{A} .7)
\end{aligned}
$$

となることから, 角度範囲条件である式 (A.7) が成立してい るとき, 駆動㐘車と被動歯車のピッチ曲線は幾何的に同一とな る.すなわち式 (A.7) は, 対数らせん歯車対の同一形状条件と なる。

\section{付録 A. $3 \rho^{2}$-Spring の変位一負荷特性}

一対の対数らせん歯車対によって構成される $\rho^{2}$-Spring の変 


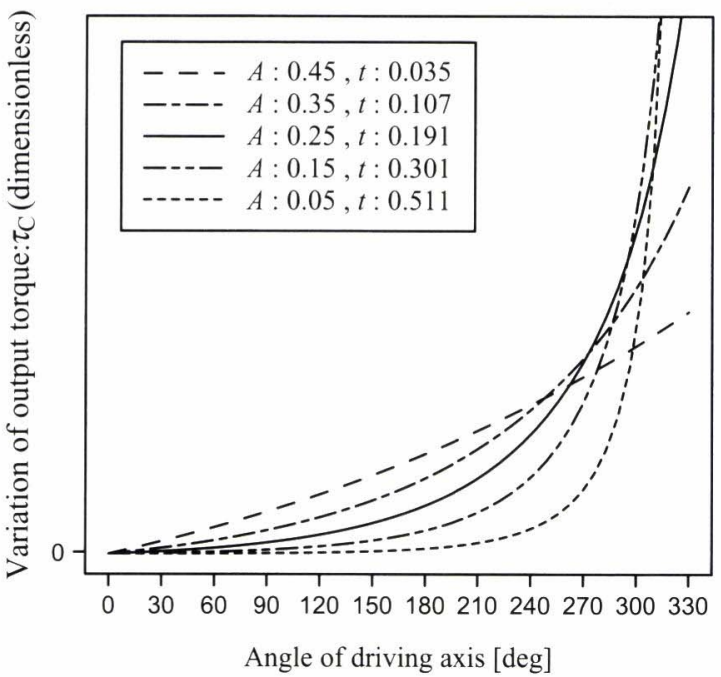

Fig. 17 Nonlinearity of $\rho^{2}$-Spring using identical logarithmic spiral gears

位一負荷特性 $\tau_{\mathrm{C}}(\theta)$ は, 式 (13) に打いて $n=1$ を代人すると, $G_{1,2}\left(\theta_{1}\right)$ は式 (A.2) に相当することから，

$$
\tau_{\mathrm{C}}(\theta)=\frac{A \exp \left(t \theta_{1}\right)}{C-A \exp \left(t \theta_{1}\right)} \cdot \tau_{\mathrm{u}}\left(\frac{1}{t} \log \frac{C-A}{C-A \exp \left(t \theta_{1}\right)}\right)
$$

と求められる.

Fig. 17 に, 同一形状条件（式 (A.7) ) を満たしている対数 らせん菌車をつかった $\rho^{2}$-Spring の, 変位一負荷特性の一例を示 す。この図では, 対数らせん歯車の各パラメータ $A, C, t, \theta_{\mathrm{e}}$ によって, 変位一負荷特性の非線形性がどのように変化するかに 注目する，そのため被動軸に接続される弾性源は， $\tau_{\mathrm{u}}(\theta)=k \theta$ なる線形バネ在使用し， $C=1, \theta_{\mathrm{e}}=330[\mathrm{deg}]$ と固定する。こ のとき式 (A.9) は

$$
\tau_{\mathrm{C}}(\theta)=k \frac{1}{t} \frac{A \exp \left(t \theta_{1}\right)}{C-A \exp \left(t \theta_{1}\right)} \cdot \log \left(\frac{C-A}{C-A \exp \left(t \theta_{1}\right)}\right)
$$

となるが，変化だけに注目するためにバネ係数 $k$ を無視し無次 元化した

$$
\hat{\tau_{\mathrm{C}}}(\theta)=\frac{1}{t} \frac{A \exp \left(t \theta_{1}\right)}{C-A \exp \left(t \theta_{1}\right)} \cdot \log \left(\frac{C-A}{C-A \exp \left(t \theta_{1}\right)}\right)
$$

をプロットした. $A=0.5$ では対数らせん㐘車は円形歯車とな る. $A=0.45$ ではほほ線形の特性を示しているが, $A$ を減じ るにつれ，非常に強い非線形性を示すことが分かる．非線形性 が強いほど剛性設定範囲の広い拮抗駆動型可変剛性関節を構成

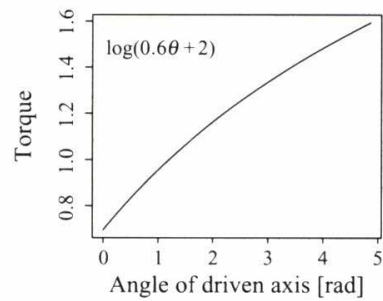

(a) Elasticity source with driven axis

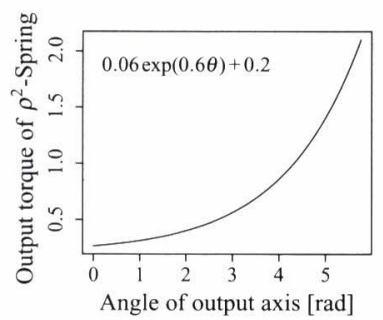

(b) Desired characteristics
Fig. 18 Example of characteristics curve

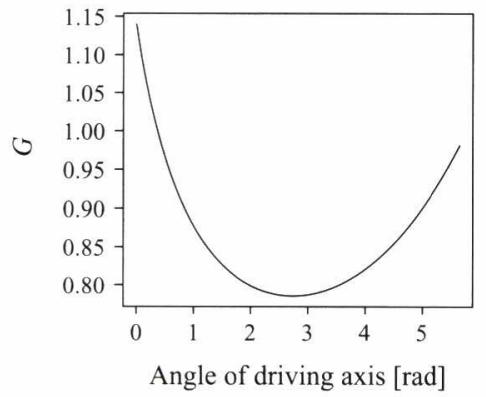

Fig. 19 Generated angular velocity ratio $G$

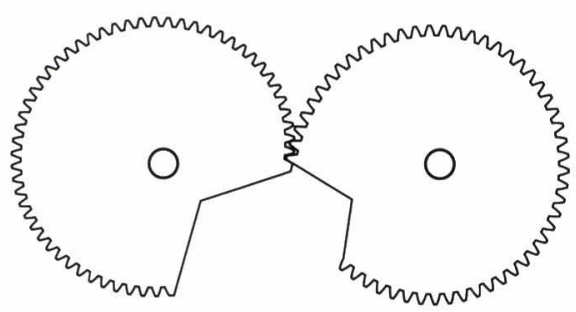

(a) Driven gear (b) Driving gear

Fig. 20 Complete contours of generated noncircular gears

できるので，この意味でも有用な形状であるといえる．

\section{付録 B. $\rho^{2}$-Spring の設計例}

本論文で示した，任意の変位一負荷特性を持つ $\rho^{2}$-Spring の設 計法についての設計例を示す。

Fig. 18 (b) に示す特性を持つ $\rho^{2}$-Spring が必要であり, Fig. 18 (a) に示す特性を持つ弾性源が使用できるものとする.

このとき，第 6 章で示した手法を使うことで，角速度比 $G$ は 数值計算することができる (Fig. 19)。角速度比 $G$ から非円形 㐘車対の輪郭を求める手法は確立されており [11], それによっ て生成した歯形を Fig. 20 に示す.

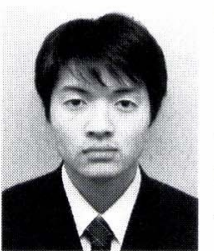

松田壮史（Takeshi Matsuda）

1980 年 6 月 12 日生. 2004 年東京工業大学工学部 制御システム工学科卒業. 2006 年東京工業大学大 学院総合理工学研究科知能システム科学専攻修士課 程修了．現在株式会社インクスに勤務。生産技術開 発 (金型)に従事. 現在に至る。

(日本ロボット学会正会員)

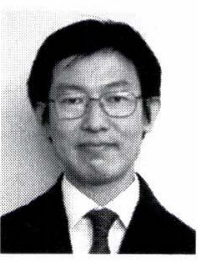

村田 智（Satoshi Murata）

1962 年 6 月 4 日生. 1987 年名古屋大学大学院工 学研究科博士前期課程航空工学専攻修了。1987 年 通商産業省工業技術院機械技術研究所研究員. 博士 (工学)。2001 年より東京工業大学大学院総合理工 学研究科知能システム科学専攻助教授. 計測自動制 御学会, 日本機械学会, かたちの科学会, IEEE な どの正会員.

(日本ロボット学会正会員) 